\title{
The First Case of Immunity Loss and SARS-CoV-2 Reinfection by the Same Virus Lineage in Amazonia
}

\author{
Lucas Ferrante $^{1}$ (D) Sophia Livas ${ }^{2}$ - Wilhelm Alexander Steinmetz ${ }^{3}$. Alexandre Celestino Leite Almeida ${ }^{4}$. \\ Jeremias Leão ${ }^{5}$. Ruth Camargo Vassão ${ }^{6}$. Unaí Tupinambás ${ }^{7} \cdot$ Philip Martin Fearnside $^{8} \cdot$ Luiz Henrique Duczmal $^{9}$
}

Received: 3 February 2021 / Revised: 22 May 2021 / Accepted: 7 June 2021 / Published online: 21 June 2021

(C) W. Montague Cobb-NMA Health Institute 2021

\begin{abstract}
We report the first confirmed record of a SARS-CoV-2 immunity loss and reinfection for the Amazon region and for Brazil by the same virus lineage. The patient presented an asymptomatic condition the first time and an aggravated one after reinfection. We raise the possibility of a recessive genotype in the Amazonian population that does not generate an immune memory response to SARS-CoV-2.
\end{abstract}

Keywords Amazonas · COVID-19 · Immunity loss · Manaus

Cases of reinfection by SARS-CoV-2 have been reported for various locations around the world [1,2]. We report a case in Manaus, the capital of Brazil's state of Amazonas - the first confirmed record of immunity loss with a SARS-CoV-2 reinfection for the Amazon region and for Brazil. The patient is a 24-year-old woman without comorbidities, $1.78 \mathrm{~m}$ in height and weighing $75 \mathrm{~kg}$. The patient (Sophia Livas, the second author of this study) tested positive the first time on July 9, 2020 with a rapid test, showing no symptoms, confirmed on the same day by two RT-PCR tests (sample type: oropharyngeal swab) for SARS-CoV-2 and tested positive for IgM and negative for IgG. An RT-PCR test (oropharyngeal swab sample) performed 60 days after the date of the first infection showed the absence of SARS-CoV-2. The first symptoms of reinfection were noticed on October 25, or 109 days after the

Lucas Ferrante

lucasferrante@hotmail.com

1 Programa de Pós-Graduação em Biologia (Ecologia), Instituto Nacional de Pesquisas da Amazônia (INPA), Manaus, Amazonas, Brazil

2 Programa de Pós-Graduação em Saúde, Sociedade e Endemias na Amazônia (PPG-SEA-M), Universidade Federal do Amazonas (UFAM), Manaus, Amazonas, Brazil

3 Department of Mathematics, Universidade Federal do Amazonas (UFAM), Manaus, Amazonas, Brazil

4 Universidade Federal de São João del-Rei (UFSJ)—DEFIM, Ouro Branco, Minas Gerais, Brazil first infection, with no symptoms of COVID-19 during this period.

The symptoms of reinfection started with a sudden headache at different times during the day, body pain that, according to the patient, was more constant in the afternoon than at other times of day, an inflammation in the throat, odynophagia, nasal congestion, tiredness and fatigue, chest pain, lack of appetite, increased blood pressure and tachycardia. The patient tested positive for IgM and negative for IgG on October 29, the reinfection being confirmed by an RT-PCR test that indicated potential transmissibility. The symptoms worsened from October 30 to November 2 , when the patient reported fatigue even while speaking. In the critical period, the patient had a heart rate of 125 beats per minute, blood pressure of 190/100 $\mathrm{mm} \mathrm{Hg}$ and body temperature of $39.5^{\circ} \mathrm{C}\left(103{ }^{\circ} \mathrm{F}\right)$. On November 8 , the patient had no more

5 Department of Statistics, Universidade Federal do Amazonas (UFAM), Manaus, Amazonas, Brazil

6 Cell Biology Laboratory of the Instituto Butantan—São Paulo, São Paulo, Brazil

7 Department of Internal Medicine, Universidade Federal de Minas Gerais (UFMG), Belo Horizonte, Minas Gerais, Brazil

8 Departamento de Dinâmica Ambiental, Instituto Nacional de Pesquisas da Amazônia (INPA), Manaus, Amazonas, Brazil

9 Department of Statistics, Universidade Federal de Minas Gerais (UFMG), Belo Horizonte, Minas Gerais, Brazil 
symptoms, returning to practice regular physical activities during the month of December. On January 4, 2021, the patient again experienced fatigue and tachycardia, in addition to new symptoms such as diarrhea and a drop in blood pressure. A new antibody test showed IgM but not IgG production.

Although patients who have recovered from COVID-19 show a reduction in levels of antibodies of type $\operatorname{IgG}$ [3], this patient had no IgG antibodies since the first contact with SARS-CoV-2, a factor implying with a greater risk of reinfection [4]. In addition, the patient did not produce IgG antibodies even after reinfection with severe symptoms. The absence of an immune response in the form of IgG antibodies, both at first contact and on reinfection, indicates that individuals may not acquire natural immunity to SARS-CoV-2, undermining expectations of herd immunity.

The period from the first infection by SARS-CoV-2 to the first symptoms of reinfection was 109 days. The existence of a negative laboratory test for SARS-CoV-2 and an asymptomatic period longer than 90 days between the first infection and reinfection meet the epidemiological criteria established by the Pan American Health Organization, the World Health Organization and Centers for Disease Control and Prevention (CDC) to classify as a reinfection by SARSCoV-2 [5, 6]. Although we have not performed sequencing for comparison with other strains, the reinfection caused by the new strain of Amazonian (P1) origin is ruled out due to its estimated appearance between December 2020 and January 2021; other variants are also not plausible since there is no record of these for the Amazon region [7, 8].

It is likely that the third and most serious manifestation of the disease, observed in January 2021, was due to the P1 variant, since the antibody test showed IgM but not IgG production and the P1 variant was the predominant variant in Manaus in January 2021 [7-9], which suggests that reinfection this month could have occurred either by the same variant or by the P1 variant. Since the two previous infections did not protect against an additional reinfection in January even if the January infection was by the original variant, this reinforces the argument that immunity from natural contact with the virus is not guaranteed.

This case study warns of the possibility of reinfection by the same strain of SARS-CoV-2 for patients who do not generate an immune response to the coronavirus, as noted by the absence of IgG production. The observed data lead us to raise the hypothesis of the existence of a recessive genotype within the population of Manaus that does not generate an immune response to the coronavirus. Various cases of reinfection in Amazonas have been reported [10], even before the appearance of new strains in the region [7, 8]. Manaus has a mixed population with many residents of indigenous descent, and the vulnerability due to genetic factors of indigenous peoples and their descendants to respiratory diseases caused by viruses reinforces this hypothesis [11].
Confirmation of reinfection in the Amazon region is an essential alert for Brazil because of the potential of infections to overwhelm the health system, as occurred during the first wave in Manaus [11]. It is also important because of the vulnerability of traditional communities, including indigenous peoples in the region $[11,12]$. The risk to the health system is due to the demand for ICU beds for individuals exposed to SARS-CoV-2 being added for the first time is added to the demand from re-infected patients who may have more serious symptoms due to long-term effects from a previous infection.

Data from the Foundation for Health Surveillance of the state of Amazonas (FVS) confirm that the second wave was bigger than the first, starting 21 days after the return of face-to-face classes in public schools on September 24, 2020 [13]. None of the population had been vaccinated at that time. By April 21, 2021, Brazil had vaccinated $13 \%$ of its entire population with the first dose of a vaccine and $5 \%$ of the population with the second dose [14]. Less than $15 \%$ of the population of Manaus had received the first dose of a vaccine, and $5 \%$ had received the second dose as of the same date; the elderly and health and public-safety professionals had been the priority groups [15]. Records of infection by the P1 variant have been observed in younger individuals than previously, and there was an increase in infections and hospitalizations in the 18-49-year age group [16], which is the age group not yet covered by the vaccine. The data in this case study confirm the possibility of reinfection not only by different variants [1, 2], but also by the same variant. Epidemiological models predict a third wave for Manaus, considering the current rates of immunization by vaccination $[9,17]$. The possibility of unvaccinated people being re-infected by either the same or a different variant of SARS-CoV-2, together with the low immunization rates by vaccination and the loosening of restrictive measures (such as the planned resumption of face-to-face classes in the second half of May), points to the continuity of the pandemic in Amazonas and in Brazil.

\section{Conclusion}

Here we report the case of a patient who did not generate an immune response to SARS-CoV-2. This case suggests the possibility of a recessive genotype within the population preventing generation of a natural immune response to the coronavirus, making reinfection possible by the same strain to which the individual originally became infected. These results are particularly important as the record is from Manaus, one of the world's cities with the most critical situation in the COVID-19 pandemic. In addition, given the low rate of immunization via vaccination of the Brazilian population and the possibility of reinfection by either the same or by a different variant, continuation of the country's pandemic is expected. 
Acknowledgements This study was supported by the Conselho Nacional de Desenvolvimento Científico e Tecnológico (CNPq) and Fundação de Amparo à Pesquisa do Estado do Amazonas (FAPEAM).

Author Contribution LF conceived of the idea; LF, SL, WAS, ACLA, JL, RCV, UT, PMF and LHD wrote the manuscript; LF, SL, WAS, ACLA, JL, RCV, UT, PMF and LHD revised the manuscript.

\section{Declarations}

Ethics Approval Plataforma Brasil ethics committee case no. CAAE 48196021.4.0000.0005.

Conflict of Interest The authors declare no competing interests.

\section{References}

1. ECDC. Reinfection with SARS-CoV-2: considerations for public health response. ECDC. 2020; https://bityl.co/5T1h

2. Prado-Vivar B, Becerra-Wong M, Guadalupe JJ, Márquez S, Gutierrez B, Rojas-Silva P, et al. A case of SARS-CoV-2 reinfection in Ecuador. Lancet Infect Dis. 2020;21:e142. https://doi.org/ 10.1016/S1473-3099(20)30910-5.

3. Yang OO, Ibarrondo FJ. Loss of anti-SARS-CoV-2 antibodies in mild COVID-19. N Engl J Med. 2020;383:1697-8. https://doi.org/ 10.1056/nejmc2027051.

4. Lumley SF, O'Donnell D, Stoesser NE, et al. Antibody status and incidence of SARS-CoV-2 infection in health care workers. N Engl J Med. 2020;384:533-40. https://doi.org/10.1056/ NEJMoa2034545.

5. $\mathrm{PAHO} / \mathrm{WHO}$. Interim guidelines for detecting cases of reinfection by SARS-CoV-2. PAHO/WHO. 2020; https://bityl.co/5T1y

6. CDC. Reinfection with COVID-19. Centers for Disease Control and Prevention. 2020; https://www.cdc.gov/coronavirus/2019ncov/your-health/reinfection.html

7. Naveca $\mathrm{F}$ et al. Phylogenetic relationship of SARS-CoV-2 sequences from Amazonas with emerging Brazilian variants harboring mutations $\mathrm{E} 484 \mathrm{~K}$ and $\mathrm{N} 501 \mathrm{Y}$ in the Spike protein. virological.org. 2021; https://bityl.co/5Chi

8. Naveca F, Costa CF. Caracterização genética do SARS-CoV-2 circulante no Estado do Amazonas. FioCruz/FVS. 2021; https:// amz.run/4GZF

9. Ferrante L. et al. Nota técnica: Necessidade de lockdown e vacinação abrangente em Manaus para contenção da pandemia da COVID-19. Instituto Nacional de Pesquisas da Amazônia. INPA, DOI: https://doi.org/10.13140/RG.2.2.17456.48641. 2021; https:// bityl.co/5arD

10. O Globo. Médico de Parintins relata reinfecção pelo coronavírus. O Globo. 2020; https://bityl.co/5T22

11. Ferrante L, Fearnside PM. Protect Indigenous peoples from COVID-19. Science. 2020;368:251-25251. https://doi.org/10. 1126/science.abc0073.

12. Ferrante L, Steinmetz WA, Almeida ACL, Leão J, Vassão RC, Tupinambás U, et al. Brazil's policies condemn Amazonia to a second wave of COVID-19. Nat Med. 2020;26:1315. https://doi. org/10.1038/s41591-020-1026-x.

13. FVS. Boletim diário COVID-19 no Amazonas 31/12/2020. FVS. 2020; https://bityl.co/5nAD

14. G1. Brasil aplicou ao menos uma dose de vacina contra Covid em mais de 27,5 milhões de pessoas, aponta consórcio de veículos de imprensa. G1. 2021; https://tinyurl.com/5b2z6fuz

15. FVS. Vacinação no Amazonas. Available at 21 april 2021. FVS. 2021; https://www.fvs.am.gov.br/indicadorSalaSituacao_view/75/ 2

16. G1. Fiocruz diz que dados apontam aumento expressivo dos casos de Covid entre os mais jovens. G1. 2021; https://g1.globo.com/ bemestar/coronavirus/

17. Ferrante L. et al. Nota técnica: Reavaliação da pandemia de COVID-19 em Manaus e necessidade de medidas restritivas para conter a terceira onda. Instituto Nacional de Pesquisas da Amazônia \& Universidade Federal de Minas Gerais (INPA/UFMG). 10.13140/RG.2.2.31876.45444. 2021; https://bityl.co/6PAv

Publisher's Note Springer Nature remains neutral with regard to jurisdictional claims in published maps and institutional affiliations. 